\title{
Upaya Meningkatkan Hasil Belajar Siswa pada Pembelajaran Tematik Sub Tema Pengaruh Perubahan Cuaca terhadap Kehidupan Manusia Menggunakan Metode The Learning Cell di Kelas III A SDN Bulu Lor Semarang
}

\author{
Puji Hastuti \\ SDN Bulu lor Semarang \\ pujihastuti.suroto@gmail.com
}

\begin{abstract}
The thematic learning process in class III A Bulu Lor, North Semarang District has so far been carried out using the lecture, dictation and question and answer method so that students only receive material passively, and the teacher is more active, judging from classical completeness as long as using conventional methods only around $48 \%$ of 34 students. To overcome this, one of the appropriate learning methods applied to realize active learning is the learning cell method. This study is intended to answer the following problems: 1) How is the application of the learning cell method in the thematic learning of the sub-theme of the effect of weather changes on human life in class III A SDN Bulu Lor, North Semarang District, for the 2019/2020 academic year?. 2) Is there an increase in learning outcomes in the thematic learning of the sub-theme of the effect of weather changes on human life in class III A SDN Bulu Lor North Semarang District in the 2019/2020 academic year after applying the learning cell method?. These problems are discussed through classroom action research which is carried out through 2 cycles with each cycle the stages are planning, action, observation and reflection. The results showed that: 1) The application of the learning cell method in the thematic learning of the sub-theme of the influence of weather changes on human life in class III A SDN Bulu Lor, North Semarang District, for the 2019/2020 academic year, made students active in the learning process by complementing each other's answers. which initially only listened and answered questions from the teacher, the student's learning cell method has become the subject of learning while the teacher only serves as a motivator who provides encouragement and guidance to students in order to achieve maximum learning outcomes 2) There is an increase in learning outcomes in thematic learning sub-themes influence weather changes on human life in class III A SDN Bulu Lor North Semarang District in the 2019/2020 academic year after applying the learning cell method, this can be seen from the increase in learning outcomes per cycle where in the pre-cycle students who complete there are 13 students or $46.43 \%$ cycle I there are 19 students a tau $67.9 \%$, and in the second cycle there were 25 students or $89.3 \%$. These results indicate that the results are in accordance with the indicators determined by KKM 70 to get $80 \%$ results. Likewise with the active learning, which increased in the first cycle there were 16 students or 57.1\%, and in the second cycle there were 26 students or $92.9 \%$. These results are in accordance with the indicators, namely the active category once and $80 \%$ active.
\end{abstract}

Keywords: learning, thematic, learning cell

Proses pembelajaran tematik di kelas III A Bulu Lor Kecamatan Semarang Utara selama ini yang dilakukan dengan menggunakan metode ceramah, mendikte dan tanya jawab sehingga menjadikan siswa hanya menerima materi secara pasif, dan gurulah yang lebih aktif, di lihat dari ketuntasan klasikal selama menggunakan metode konvensional hanya berkisar $48 \%$ dari 34 siswa. Untuk mengatasi itu salah satu metode pembelajaran yang tepat diterapkan untuk mewujudkan pembelajaran aktif adalah metode the learning cell (sel belajar). Studi ini dimaksudkan untuk menjawab permasalahan: 1) Bagaimanakah penerapan metode the learning cell pada pembelajaran tematik sub tema pengaruh perubahan cuaca terhadap kehidupan manusia di kelas III A SDN Bulu Lor Kecamatan Semarang Utara Tahun Pelajaran 2019/2020?. 2) Adakah peningkatan hasil belajar pada pembelajaran tematik sub tema pengaruh perubahan cuaca terhadap kehidupan manusia di kelas III A SDN Bulu Lor Kecamatan Semarang Utara Tahun Pelajaran 2019/2020 setelah menerapkan metode the learning cell?. Permasalahan tersebut di bahas melalui penelitian tindakan kelas yang dilakukan melalui 2 siklus dengan setiap siklus tahapannya adalah perencanaan, tindakan, observasi dan refleksi. Hasil penelitian menunjukkan bahwa: 1) Penerapan metode the learning cell pada pembelajaran tematik sub tema pengaruh 
perubahan cuaca terhadap kehidupan manusia di kelas III A SDN Bulu Lor Kecamatan Semarang Utara Tahun Pelajaran 2019/2020 menjadikan siswa aktif dalam melakukan proses belajar dengan saling melengkapi jawaban dari yang semula hanya mendengarkan dan menjawab pertanyaan dari guru, metode the learning cell siswa telah menjadi subyek pembelajaran sedangkan guru hanya bertugas sebagi motivator yang memberikan semangat dan bimbingan kepada siswa agar tercapai hasil belajar yang maksimal 2) Ada peningkatan hasil belajar pada pembelajaran tematik sub tema pengaruh perubahan cuaca terhadap kehidupan manusia di kelas III A SDN Bulu Lor Kecamatan Semarang Utara Tahun Pelajaran 2019/2020 setelah menerapkan metode the learning cell, hal ini dapat dilihat dari peningkatan hasil belajar per siklus dimana pada pra siklus siswa yang tuntas ada 13 siswa atau $46.43 \%$ siklus I ada 19 siswa atau $67.9 \%$, dan pada siklus II sudah mencapai ada 25 siswa atau 89.3\%. Hasil tersebut menunjukkan bahwa hasil tersebut sesuai dengan indikator yang ditentukan dengan KKM 70 mendapatkan hasil sebanyak $80 \%$. Begitu juga dengan keaktifan belajarnya yaitu mengalami kenaikan pada siklus I ada 16 siswa atau 57.1\%, dan pada siklus II sudah mencapai ada 26 siswa atau 92.9\%. Hasil tersebut sesuai dengan indikator yaitu kategori aktif sekali dan aktif sebanyak $80 \%$.

Kata Kunci : belajar, tematik, learning cell

\section{PENDAHULUAN}

Pembelajaran tematik adalah pembelajaran yang lebih menekankan pada penerapan konsep belajar sambil melakukan sesuatu (learning by doing). Oleh karena itu, guru perlu mengemas atau merancang pengalaman belajar yang akan dipengaruhi kebermaknaan belajar siswa. Pengalaman belajar yang menunjukkan kaitan unsur-unsur konseptual menjadikan proses pembelajaran lebih efektif. Kaitan konseptual antar mata pelajaran yang dipelajari akan membentuk skema sehingga siswa akan memperoleh keutuhan dan kebulatan pengetahuan. Selain itu, dengan penerapan pembelajaran tematik di sekolah dasar akan sangat membantu siswa karena sesuai dengan tahap perkembangannya yang masih melihat segala sesuatu sebagai satu hukum (holistic) (Dimyati dan Mudjiono, 2009: 45).

Proses pembelajaran tematik khususnya pada sub tema pengaruh perubahan cuaca terhadap kehidupan manusia di kelas III A SDN Bulu Lor Kecamatan Semarang Utara, selama ini yang dilakukan lebih banyak dengan menggunakan metode ceramah, mendikte dan tanya jawab sehingga menjadikan siswa hanya menerima materi secara pasif, dan gurulah yang lebih aktif, di lihat dari ketuntasan klasikal selama menggunakan metode konvensional hanya berkisar $46 \%$ dari 34 siswa (Observasi dan Dokumentasi nilai hasil belajar kelas kelas III A SDN Bulu Lor Kecamatan Semarang Utara.

Menurut E. Mulyasa (2004: 99) Keberhasilan dapat dilihat dari jumlah peserta didik yang mampu menyelesaikan/ mencapai minimal $65 \%$, sekurang-kurangnya $75 \%$ dari jumlah peserta didik yang ada di kelas tersebut, maksudnya yaitu sekurang-kurangnya $75 \%$ dari keseluruhan peserta didik yang ada di kelas tersebut memperoleh nilai 65 atau mencapai ketuntasan belajar $65 \%$ (Mulyasa, 2004: 99).

Untuk mengatasi itu salah satu metode pembelajaran yang tepat diterapkan untuk mewujudkan pembelajaran aktif adalah metode the learning cell (sel belajar). Metode the 
learning cell ini adalah salah satu dari beberapa sistem terbaik untuk membantu pasangan peserta didik belajar dengan efektif, sistem pembelajaran ini merupakan pembelajaran kooperatif dalam bentuk pasangan, peserta didik bertanya dan menjawab pasangan secara bergantian pada materi yang sama.

Dari uraian di atas maka peneliti tertarik untuk meneliti lebih jauh tentang upaya guru untuk meningkatkan hasil belajar siswa pada pembelajaran tematik sub tema pengaruh perubahan cuaca terhadap kehidupan manusia di kelas III A SDN Bulu Lor Kecamatan Semarang Utara Tahun Pelajaran 2019/2020.

\section{KAJIAN TEORI}

Menurut tim penyusun Kamus Besar Bahasa Indonesia., "Hasil belajar atau prestasi belajar adalah penguasaan pengetahuan atau ketrampilan yang dikembangkan oleh mata pelajaran, lazimnya ditunjukkan dengan nilai tes atau angka nilai yang diberikan oleh guru" (Alwi, 2008: 895). Menurut Abdurrahman (2003: 37), "Hasil belajar adalah kemampuan yang diperoleh anak setelah melalui kegiatan belajar". Menurut. Winkel (2004: 48) "Hasil belajar adalah perubahan sikap atau tingkah laku setelah anak melalui proses belajar". Jadi hasil adalah penguasaan pengetahuan atau keterampilan yang dikembangkan oleh mata pelajaran lazimnya yang ditunjukkan dengan nilai tes atau angka nilai yang diberikan oleh guru.

Pembelajaran tematik merupakan pola pembelajaran yang mengintegrasikan pengetahuan, ketrampilan, kreativitas, nilai dan sikap pembelajaran dengan tema (Mamat, 2002: 3). Berdasarkan berbagai definisi sebagaimana yang telah dikemukakan tersebut, pada dasarnya mendukung bahwa kurikulum terpadu adalah pendekatan edukasional yang mempersiapkan siswa untuk menghadapi pembelajaran seumur hidup.

Metode the learning cell. Metode the learning cell adalah salah satu dari beberapa sistem terbaik untuk membantu pasangan peserta didik belajar dengan efektif, dimana sistem pembelajaran ini merupakan pembelajaran kooperatif dalam bentuk pasangan, dimana peserta didik bertanya dan menjawab pasangan secara bergantian pada materi yang sama (Zaini, 2008: 86).

Hipotesis tindakan merupakan tindakan yang di duga akan dapat memecahkan masalah yang ingin diatasi dengan penyelenggaraan PTK (Subyantoro, 2009: 43). Hipotesis tindakan dalam penelitian ini adalah metode the learning cell dapat meningkatkan hasil belajar pada pada pembelajaran tematik sub tema pengaruh perubahan cuaca terhadap kehidupan manusia di kelas III A Bulu Lor Kecamatan Semarang Utara Tahun Pelajaran 2019/2020. Sedangka kerangka berpikir dapat dilihat pada gambar berikut. 


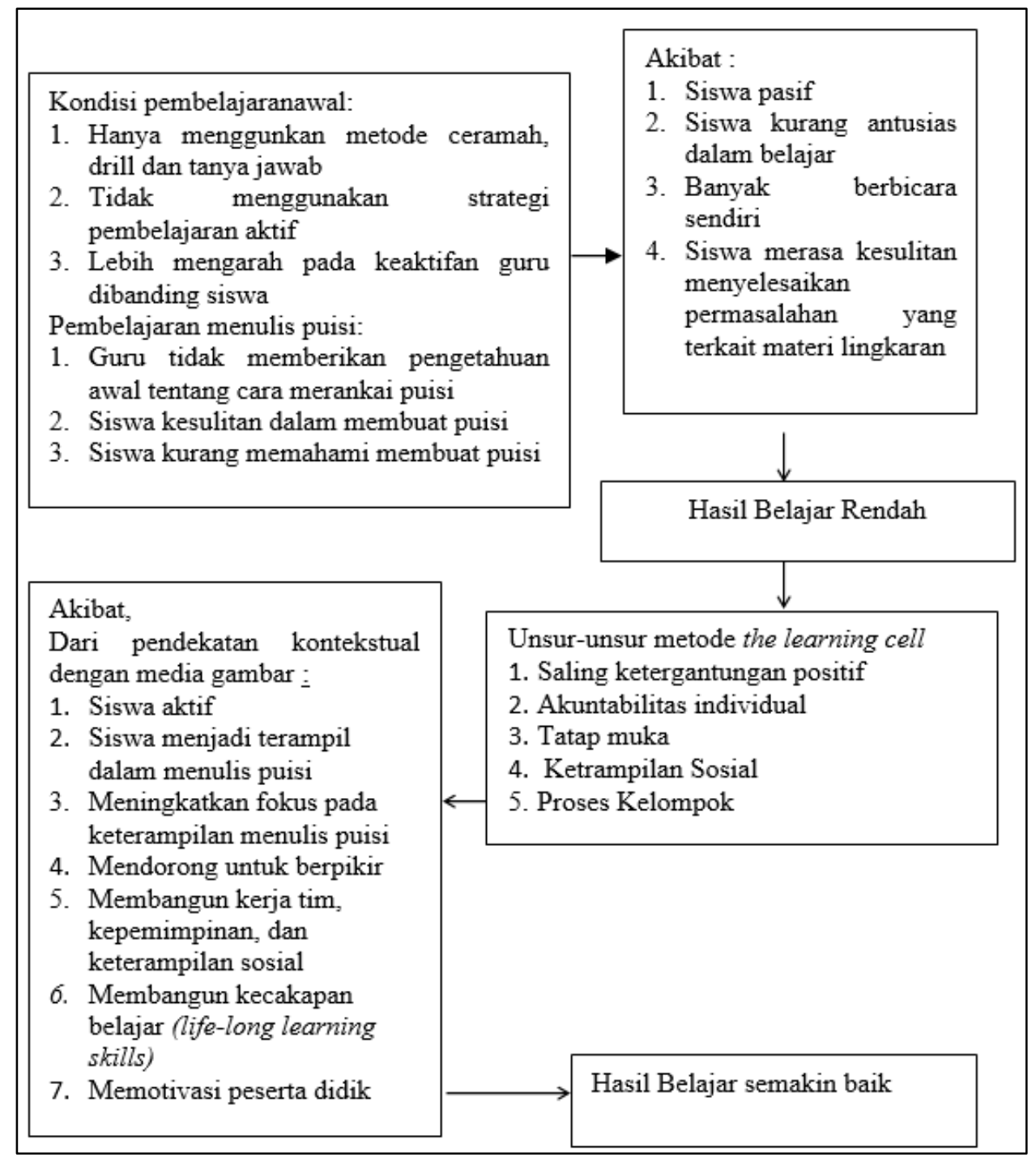

Gambar 1. Kerangka Berpikir

\section{METODE PENELITIAN}

Penelitian ini merupakan penelitian tindakan kelas (classroom action research). Menurut Rochiarti Wiriatmadja penelitian tindakan kelas yang dimaksud adalah kajian sistematik dari upaya perbaikan pelaksanaan praktik pendidikan oleh sekelompok guru dengan melakukan tindakan-tindakan dalam pembelajaran, berdasarkan refleksi mereka mengenai hasil dari tindakan-tindakan tersebut (Wiriatmadja, 2006 :12). Penelitan dengan model tindakan langsung akan mampu meningkatkan kualitas pembelajaran

Tempat penelitian SDN Bulu Lor Kecamatan Semarang Utara. Penelitian ini dilakukan pada tanggal 06 Januari 2020 sd 20 Maret 2020. Adapun subjek dalam penelitian ini adalah seluruh siswa kelas III A SDN Bulu Lor Kecamatan Semarang Utara Tahun Pelajaran 2019/2020 sejumlah 36 siswa. 
Prosedur penelitian yang digunakan peneliti adalah prosedur tindakan kelas Lewin spiral of steps yaitu setiap langkah terdiri atas empat tahap, yaitu perencanaan, tindakan, observasi, dan refleksi (Basrowi dan Suwandi, 2008 : 27).Untuk lebih jelasnya rangkaian ini dapat dilihat pada gambar berikut ini:

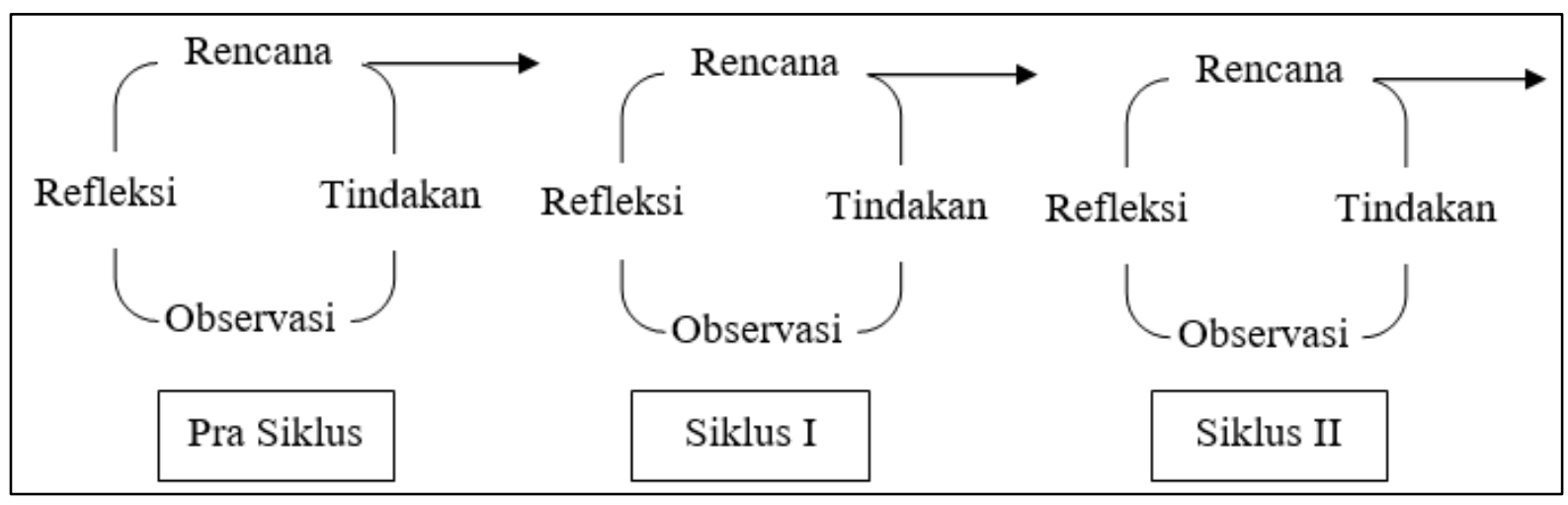

Gambar 2. Prosedur Penelitian

Teknik Pengumpulan Data

1. Metode Observasi

Metode observasi diartikan sebagai pengamatan dan pencatatan secara sistematik terhadap gejala yang tampak pada obyek penelitian (Margono, 2004 :158).

Dalam kegiatan ini yang diobservasi secara langsung adalah keaktifan siswa dan aktivitas guru pada proses pelaksanaan metode the learning cell pada pembelajaran tematik sub tema pengaruh perubahan cuaca terhadap kehidupan manusia di kelas III A SDN Bulu Lor Kecamatan Semarang Utara.

2. Metode Tes

Adalah seperangkat rangsangan (stimuli) yang mendapat jawaban yang dapat dijadikan dasar bagi penetapan skor angka (Margono, 2004: 170). Metode tes ini digunakan untuk mengetahui hasil belajar siswa pada pembelajaran tematik sub tema pengaruh perubahan cuaca terhadap kehidupan manusia di kelas III A SDN Bulu Lor Kecamatan Semarang Utara.

3. Metode Dokumentasi

Metode dokumentasi yaitu mencari data mengenai hal-hal atau variabel yang berupa catatan, buku, transkip, surat kabar majalah, prasasti, notulen rapat, legger, agenda dan sebagainya (Arikunto, 2006: 206). Metode ini digunakan untuk memperoleh data dokumen tentang metode the learning cell pada pembelajaran tematik sub tema pengaruh perubahan cuaca terhadap kehidupan manusia di kelas III A SDN Bulu Lor Kecamatan Semarang Utara seperti RPP, LOS dan daftar nama siswa. 
Data-data yang diperoleh dari penelitian baik melalui pengamatan, tes atau dengan menggunakan metode yang lain kemudian diolah dengan analisis deskriptif dan prosentase untuk menggambarkan keadaan peningkatan pencapaian indikator keberhasilan tiap siklus. Berikut rumus prosentase dengan sebagai berikut:

$$
\text { Nilai }=\frac{\text { Skor yang dicapai }}{\text { Jumlah siswa }} \times 100 \%
$$

Sedangkan untuk mengetahui tingkat keberhasilan penelitian tindakan ini apabila:

1. Meningkatnya hasil belajar dengan KKM 70 sebanyak $80 \%$ dari jumlah peserta didik.

2. Adanya peningkatan keaktifan belajar peserta didik pada kategori aktif dan aktif sekali yang mencapai $80 \%$.

\section{HASIL DAN PEMBAHASAN}

Tindakan pra siklus dilakukan dengan metode konvensional dengan tanya jawab dan ceramah, diperbaiki dengan menggunakan metode the learning cell yang mengarah pada pemberian keaktifan belajar siswa pada siklus I dan siklus II diperbaiki lagi dengan mengaktifkan siswa melalui media gambar dan praktek saling berpasangan, lebih banyak memotivasi belajar siswa dengan lebih banyak mengelilingi belajar siswa. Hasil kuis tiap siklus dapat digambarkan sebagai berikut:

Tabel 1. Perbandingan Hasil Belajar Pra Siklus, Siklus I dan II

\begin{tabular}{|c|c|c|c|c|c|c|c|c|}
\hline \multirow{2}{*}{ Kategori } & \multirow{2}{*}{ Nilai } & \multicolumn{2}{|c|}{ Pra Siklus } & \multicolumn{2}{c|}{ Siklus I } & \multicolumn{2}{c|}{ Siklus II } & \multirow{2}{*}{ Keterangan } \\
\cline { 3 - 9 } & & Siswa & $\%$ & Siswa & $\%$ & Siswa & $\%$ & \\
\hline Baik Sekali & $90-100$ & 6 & $18 \%$ & 10 & $29 \%$ & 16 & $47 \%$ & \multirow{2}{*}{ Tuntas } \\
Baik & $70-80$ & 12 & $35 \%$ & 14 & $41 \%$ & 15 & $44 \%$ & \\
\hline Cukup & $50-60$ & 11 & $32 \%$ & 8 & $24 \%$ & 3 & $9 \%$ & Tidak \\
Kurang & $\leq 40$ & 5 & $15 \%$ & 2 & $6 \%$ & 0 & $0 \%$ & Tuntas \\
\hline \multicolumn{2}{|r|}{ Jumlah } & 34 & $100 \%$ & 34 & $100 \%$ & 34 & $100 \%$ & \\
\hline
\end{tabular}

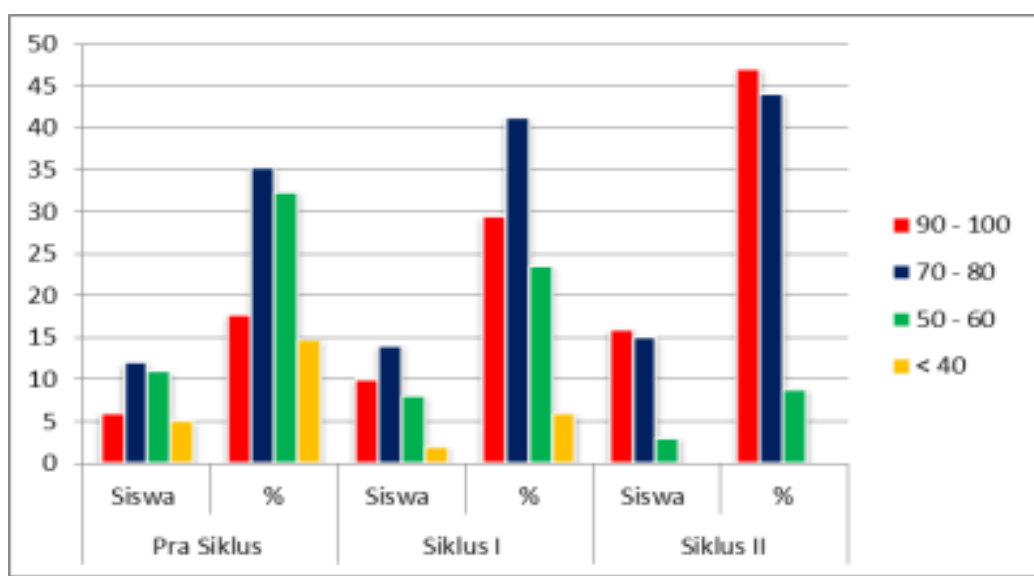

Gambar 3. Diagram Batang Perbandingan Hasil Belajar Pra Siklus, Siklus I dan Siklus II 
Hasil belajar pada pembelajaran tematik sub tema pengaruh perubahan cuaca terhadap kehidupan manusia di kelas III A SDN Bulu Lor Kecamatan Semarang Utara Tahun Pelajaran 2019/2020 setelah menerapkan metode the learning cell sesuai dengan indikator yang ditentukan dengan KKM 70 sebanyak 80\% dari jumlah peserta didik dikatakan berhasil, hal ini ditunjukkan dengan ketuntasan siswa dimana pada pra siklus ada 18 siswa atau 53\% dan pada siklus I ada 24 siswa atau $70 \%$, dan pada siklus II sudah mencapai ada 31 siswa atau $91 \%$.

Pada pra siklus berdasarkan hasil observasi yang dilakukan kolaborator aktivitas belajar siswa masih kurang aktif, siswa kurang termotivasi dalam pembelajaran, begitu juga dengan guru yang mengajar masih dominan dibanding siswa, pada siklus I aktivitas siswa semakin baik dengan penggunaan metode the learning cell karena siswa lebih diberi ruang untuk aktif dan posisi guru lebih banyak menjadi motivator, terakhir pada siklus II aktivitas siswa lebih baik dengan termotivasi dalam pembelajaran terutama dalam sistem belajar kelompok.

Keaktifan belajar pada pembelajaran tematik sub tema pengaruh perubahan cuaca terhadap kehidupan manusia di kelas III A SDN Bulu Lor Kecamatan Semarang Utara Tahun Pelajaran 2019/2020 setelah menerapkan metode the learning cell sesuai dengan indikator yang ditentukan dengan pada kategori aktif dan aktif sekali yang mencapai $80 \%$.dikatakan berhasil, dimana pada siklus I ada 24 siswa atau 70\%, dan pada siklus II sudah mencapai ada 34 siswa atau $94 \%$

Keaktifan belajar siswa pada pembelajaran tematik sub tema pengaruh perubahan cuaca terhadap kehidupan manusia di kelas III A SDN Bulu Lor Kecamatan Semarang Utara Tahun Pelajaran 2019/2020 setelah menerapkan metode the learning cell juga mengalami kenaikan yaitu aktivitas siswa dalam memperhatikan penjelasan guru 24 siswa atau $86 \%$ (mengalami kenaikan dari siklus I yaitu 18\%), aktivitas siswa dalam mengajukan pertanyaan 23 siswa atau $82 \%$ (mengalami kenaikan dari siklus I yaitu14\%), aktivitas siswa dalam kerja pasangan 24 siswa atau 86\% (mengalami kenaikan dari siklus I yaitu 22\%), aktivitas siswa dalam mengomentari hasil kerja pasangan lain 23 siswa atau 82\% (mengalami kenaikan dari siklus I yaitu 14\%).

Lebih lanjut menurut Agus Suprijono metode the learning cell sebagaimana cooperative learning akan dapat menumbuhkan pembelajaran efektif yaitu pembelajaran yang bercirikan: (1) "Memudahkan siswa belajar" sesuatu yang "bermanfaat" seperti, fakta, keterampilan, nilai, konsep, dan bagaimana hidup serasi dengan sesama (2) Pengetahuan, nilai, dan keterampilan diakui oleh mereka yang berkompeten menilai (Suprijono, 2010: 58). 
Dari penjelasan diatas menunjukkan penerapan metode the learning cell tentunya dapat meningkatkan hasil belajar pada pembelajaran tematik sub tema pengaruh perubahan cuaca terhadap kehidupan manusia di kelas III A SDN Bulu Lor Kecamatan Semarang Utara Tahun Pelajaran 2019/2020 karena siswa menjadi aktif melalui kerja pasangan dan kelompok dan saling melengkapi kekurangan anggota kelompoknya dalam memahami materi

\section{SIMPULAN}

Dari hasil penelitian dan pembahasan dapat diambil kesimpulan sebagai berikut :

1. Penerapan metode the learning cell pada pembelajaran tematik sub tema pengaruh perubahan cuaca terhadap kehidupan manusia di kelas III A SDN Bulu Lor Kecamatan Semarang Utara Tahun Pelajaran 2019/2020 menjadikan siswa aktif dalam melakukan proses belajar dengan saling melengkapi jawaban dari yang semula hanya mendengarkan dan menjawab pertanyaan dari guru, metode the learning cell siswa telah menjadi subyek pembelajaran sedangkan guru hanya bertugas sebagai motivator yang memberikan semangat dan bimbingan kepada siswa agar tercapai hasil belajar yang maksimal.

2. Ada peningkatan hasil belajar pada pembelajaran tematik sub tema pengaruh perubahan cuaca terhadap kehidupan manusia di kelas III A SDN Bulu Lor Kecamatan Semarang Utara Tahun Pelajaran 2019/2020 setelah menerapkan metode the learning cell, hal ini dapat dilihat dari peningkatan hasil belajar per siklus dimana pada pra siklus siswa yang tuntas ada 13 siswa atau $46.43 \%$ siklus I ada 19 siswa atau $67.9 \%$, dan pada siklus II sudah mencapai ada 25 siswa atau 89.3\%. Hasil tersebut menunjukkan bahwa hasil tersebut sesuai dengan indikator yang ditentukan dengan KKM 70 mendapatkan hasil sebanyak $80 \%$. Begitu juga dengan keaktifan belajarnya yaitu mengalami kenaikan pada siklus I ada 16 siswa atau 57.1\%, dan pada siklus II sudah mencapai ada 26 siswa atau 92.9\%. Hasil tersebut sesuai dengan indikator yaitu kategori aktif sekali dan aktif sebanyak $80 \%$.

\section{SARAN}

Tanpa mengurangi rasa hormat pada pihak manapun dan dengan segala kerendahan hati, peneliti juga mengajukan beberapa saran sebagai berikut:

1. Guru hendaknya dalam mengajar perlu memperhatikan kemampuan siswa, dalam hal penguasaan materi pelajaran khususnya materi sub tema pengaruh perubahan cuaca terhadap kehidupan manusia di kelas III A SDN Bulu Lor Kecamatan Semarang Utara 
Tahun Pelajaran 2019/2020 a dan menggunakan metode yang mengarah pada keaktifan siswa

2. Sekolah hendaknya meningkatkan proses pembelajaran sub tema pengaruh perubahan cuaca terhadap kehidupan manusia di kelas III A SDN Bulu Lor Kecamatan Semarang Utara Tahun Pelajaran 2019/2020 dengan menyediakan fasilitas pembelajaran yang membantu kelancaran pembelajaran tematik.

\section{DAFTAR PUSTAKA}

Admin, "belajar dan pembelajaran bermakna" http//mgips.wordpress.com/2008/04/06/ belajar-dan-pembelajaran- bermakna/

Ahmadi, Abu, Widodo Supriyono, 2001, Psikologi Belajar, Jakarta: Rineka Cipta

Alwi, Hasan, 2008, Kamus Besar Bahasa Indonesia, Jakarta; Balai Pustaka

Arikunto, Suharsimi, 2002, Dasar-Dasar Evaluasi Pendidikan, Jakarta: Bumi Aksara

Basrowi, dan Suwandi, 2008, Prosedur penelitian Tindakan Kelas, Bogor: Penerbit Ghalisa Indonesia

Dimyati dan Mudjiono, 2009, Belajar dan Pembelajaran, Jakarta: Penerbit Rineka Cipta

Gulo, W., 2002, Strategi Belajar Mengajar, Jakarta: PT Grasindo

Hamalik, Oemar, 2002, Pendidikan Guru Berdasarkan Pendekatan Kompetensi, Jakarta: Bumi Aksara

Lindgren, Henry Clay-, 2000, Educational Psychology In The Classroom, Tokyo-Japan: Modern Asia

Makruf, Imam, 2009, Strategi Pembelajaran Bahasa Arab Aktif, Semarang: Nedd's Press

Makruf, Imam, 2009, Strategi Pembelajaran Bahasa Arab Aktif, Semarang: Nedd's Press

Mamat SB, 2002, Pedoman Pelaksanaan Pembelajaran Tematik, Jakarta: Departemen Agama Direktorat Kelembagaan Agama Islam

Margono, S., 2004, Metodologi Penelitian Pendidikan, Jakarta: Rineka Cipta

Masitoh, dkk, 2004, Strategi Pembelajaran, Jakarta : Universitas Terbuka

Morgan, Clifford T., 2000, Intruduction to Psychology, New York: The MC. Hill Book Company

Mulyasa, E,, 2004, Kurikulum Berbasis Kompetensi, Bandung: Rosda Karya

Mulyasa, E., 2004, Kurikulum Berbasis Kompetensi: Konsep, Karakteristik dan Implementasi, Bandung: PT. Remaja Rosdakarya 
Nana, Sudjana, 2001, Dasar-dasar Proses Belajar Mengajar, Bandung: Sinar Baru Algensindo

Rosyadi, Khairan, 2004, Pendidikan Profetik, Yogyakarta: Pustaka pelajar

Sagala, Syaiful, 2003, Konsep dan Makna Pembelajaran, Bandung: Alfabet

Subyantoro, 2009, Penelitian Tindakan Kelas, Semarang: CV. Widya Karya

Sudijono, Anas, 2003, Pengantar Evaluasi Pendidikan, Jakarta: Raja Grafindo Persada

Sudjana, Nana, 2002, Penilaian Hasil Proses Belajar Mengajar, Bandung: Remaja Rosdakarya

Suprijono, Agus, 2010, Cooperative Learning: Teori dan Aplikasi PAIKEM, Yogyakarta: Pustaka Pelajar

Thoha, M. Chabib dan Abdul Mu'ti, 2003, PBM-PAI di Sekolah, Yogyakarta: Pustaka Pelajar

Trianto, 2010, Mengembangkan Model Pembelajaran Tematik, Jakarta: PT. Prestasi Pustakaraya

Winkel, W.S., 2004, Psikologi Pendidikan dan Evaluasi Belajar, Jakarta: Gramedia

Wiriatmadja, Rochiarti, 2006, Metode Penelitian Tindakan Kelas, Bandung: PT Remaja Rosda Karya

Woolfolk, Anita, 2008, Educational Psycology Active Learning, terj Helly Prajitno Soetjipto dan Sri Mulyantini Soetjipto, Yogyakarta: Pustaka Pelajar

Zaini, Hisyam, dkk, 2008, Strategi Pembelajaran Aktif, Yogyakarta: Pustaka Insan Madani 